\title{
"As Lucan says": Dante's Reuse of the Bellum Civile in the Monarchia and the
}

\section{Political Epistles}

Much has been written about Lucan's presence in Dante's works, especially in the Divina

Commedia. The vernacular Dante is, indeed, the medieval author whose reception of the Bellum

civile has been investigated the most thoroughly. ${ }^{1}$ Between the late nineteenth and the early

twentieth centuries, scholars such as Moore, Belloni, Proto, and Ussani produced a series of

detailed surveys on the topic; ${ }^{2}$ from the 1960s onwards, Paratore, Marsili, and others developed

this basis, highlighting that Dante's imitation of Lucan's poem involves structural affinities that

go beyond formal reverberations. ${ }^{3}$ Many later scholarly works focus on Dante's treatment of

Caesar and Cato, who in the Commedia are described in keeping with Lucan's text. ${ }^{4}$ Similarly

\footnotetext{
${ }^{1}$ For a bibliographic overview, in addition to the texts cited below, see Lucia Medeossi, "Dante e Lucano," Sileno 15 (1989): 219-33; Violetta De Angelis, "... e l'ultimo Lucano," in Dante e la "bella scola" della poesia. Autorità e sfida poetica, ed. Amilcare A. Iannucci (Ravenna: Longo, 1993), 145-202; Peter von Moos, "Lucan au Moyen Âge," in Entre histoire et littérature: Communication et culture au Moyen Âge (Florence: Sismel, 2005), 89-202; 98; Edoardo D'Angelo, "Lucan in Medieval Latin: A Survey of the Bibliography," in Brill's Companion to Lucan, ed. Paolo Asso (Leiden: Brill, 2011), 465-79; 467.

${ }^{2}$ Edward Moore, "Lucan," in Studies in Dante. First Series: Scripture and Classical Authors in Dante (Oxford: Clarendon, 1896; rpt. 1969), 228-42; Antonio Belloni, "Dante e Lucano," Giornale Storico della Letteratura Italiana 40 (1902): 128-39; Vincenzo Ussani, Dante e Lucano. Lectura Dantis Fiorentina (Florence: Sansoni, 1917); cf. Johannes Oeschger, "Antikes und Mittelalterliches bei Dante," Zeitschrift für romanische Philologie 64 (1944): 3-87; Luigi Venturi, Le similitudini dantesche ordinate, illustrate e confrontate (Florence: Sansoni, 1874); Enrico Proto, "Dante e i poeti latini," Atene e Roma 11 (1908): 23-48, 221-36; Atene e Roma 12 (1909): 7-24, 277 90; Atene e Roma 13 (1910): 79-103, 149-62; Hermann Gmelin, "Dante und die römischen Dichter," Deutsches Dante-Jahrbuch 31-32 (1953): 42-65; Walter Fischli, Studien zum Fortleben der "Pharsalia" des M. Annaeus Lucanus (Lucerne: E. Haag, 1944), 32-40.

${ }^{3}$ Ettore Paratore, "Lucano e Dante," L'Alighieri 2 (1961): 3-24; Id., Dante e Lucano. Lectura Dantis Romana (Turin: S.E.I., 1962); Id., "Lucano," Enciclopedia Dantesca III (Rome: Istituto della Enciclopedia Italiana, 1971), 697-702; Id., Tradizione e struttura in Dante (Florence: Sansoni, 1968), 25-121; Aldo Marsili, Lucano e Dante (Lucca: M. Pacini Fazzi, 1986); Eduard Fraenkel, "Lucan als Mittler des Antiken Pathos," Vorträge der Bibliothek Warburg 4 (1924): 229-57 [here quoted as "Lucan as the Transmitter of Ancient Pathos," in Lucan, ed. Charles Tesoriero (Oxford: Oxford University Press, 2010), 15-45].

${ }^{4}$ See for example Giuseppe Mazzotta, Dante, Poet of the Desert: History and Allegory in the Divine Comedy (Princeton: Princeton University Press, 1979), 14-65; William Stull and Robert Hollander, "The Lucanian Source of Dante's Ulysses," Studi Danteschi 63 (1991): 1-52; 33-42; De Angelis; Richard Weigel, "Dante's Ambivalence Towards Julius Caesar and Frederick II," Classica et Mediaevalia 51 (2000): 271-88; John A. Scott, "Cato: a Pagan Suicide in Purgatory," in Dante's Political Purgatory (Philadelphia: University of Pennsylvania Press, 1996), 69-84; Id., Understanding Dante (Notre Dame: University of Notre Dame Press, 2004), 247-50; Romano Manescalchi, "Una nuova interpretazione del Catone dantesco," Critica Letteraria 140 (2008): 419-46; Winthrop Wetherbee, "'Poeta che mi guidi': Dante, Lucan, Virgil," in Dante: The Critical Complex, vol. II, ed. Richard Lansing (New York: Routledge, 2003), 303-20; Antonio Montefusco, "La presenza di Lucano nella Comedìa: il fantasma della
} 
well-studied are Dante's appropriation of Lucan's Erichtho and Antaeus, his reuse of Lucan in representing Ulysses, and his reliance on the Bellum civile for his description of monstrosity and various aspects of Hell. ${ }^{5}$

This substantial quantity of research has disclosed Dante's direct and deep familiarity with Lucan's poem. Already in 1897, Moore pointed out that Dante mentions or quotes Lucan around fifty times, less than Virgil (around 200 times) and Ovid (around 100 times), and more than Statius (around 30 or 40 times). Sixty years later, Paratore argued that the Bellum civile is, after the Aeneid, the ancient text mostly systematically exploited by Dante, and all the later authors on the topic agree that Lucan is a central figure in Dante's poetic canon. ${ }^{6}$

However, studies of Dante's reception of the Bellum civile are strongly focused on, if not exclusively limited to, the Commedia. Although Lucan is frequently mentioned and cited also in

storia," Linguistica e Letteratura 35 (2010): 83-108; 103-4; Paul M. Clogan, "Dante's Appropriation of Lucan's Cato and Erichtho," Medievalia et Humanistica 37 (2011): 111-15; Walde, "Lucan und Dante," in Dante Alighieri und sein Werk in Literatur, Musik und Kunst bis zur Postmoderne, ed. Klaus Ley (Tübingen: Francke, 2011): 57-74; 72-73; Valter Boggione, "La custodia, la vera libertà, la colpa, la pena. Ancora sul Catone dantesco," Giornale Storico della Letteratura Italiana 189 (2012): 321-53.

${ }^{5}$ On Erichtho and related scenes, see for example Sonia Gentili, "La necromanzia di Eritone da Lucano a Dante," in Dante e il "locus Inferni." Creazione letteraria e tradizione interpretativa, ed. with Simona Foà (Rome: Bulzoni, 2000), 13-43; Robert Wilson, "Prophecy by the Dead in Dante and Lucan," Italian Studies 52 (1997): 16-37; Clogan. On Antaeus: Robert Hollander, "L'Anteo dantesco (Inferno 31.97-132)," Annali della Facoltà di lettere e filosofia dell'Università degli studi di Milano 55 (2002): 3-11; George F. Butler, "Statius, Lucan, and Dante's Giants. Virgil's Loss of Authority in Inferno XXXI," Quaderni d'Italianistica 24 (2003): 5-21.

On Ulysses: Stull-Hollander; Cristina Bon, "Lucano all'Inferno," in La divina foresta. Studi danteschi, ed. Francesco Spera (Naples: D'Auria, 2006), 71-104; 98-103; Isabella Gualandri, “'Infin che 'l mar fu sovra noi richiuso': un'eco di Lucano in Dante, Inf. XXVI 142?" in "Meminisse iuvat." Studi in memoria di Violetta de Angelis, ed. Filippo Bognini (Pisa: ETS, 2012), 435-44; cf. Montefusco, 99-103. On the Inferno: Umberto Bosco, "La gara coi classici latini (canti XXIV-XXV dell'Inferno)," in Altre pagine dantesche (Caltanissetta: Sciascia, 1987), 93-108; Bon; Steno Vazzana, "Appunti sull'eredità lucanea e staziana nel Capaneo dantesco," Rivista di Cultura Classica e Medievale 42 (2000): 297-304; Winthrop Wetherbee, The Ancient Flame: Dante and the Poets (Notre Dame: Notre Dame University Press, 2008), 61-96.

${ }^{6}$ Moore, 4; Paratore, "Lucano," 697; cf. Id., "Lucano e Dante," 3-4. Paratore's statement is reasserted by Scott, "Cato," 75; Bon, 71, 103-104. On Lucan's importance in Dante's poetic "pantheon," see for example Fischli, 33; Fraenkel, 36-41; Teodolinda Barolini, Dante's Poets: Textuality and Truth in the Comedy (Princeton: Princeton University Press, 1984), 188-96; Butler, 5-6; Wetherbee, "Poeta che mi guidi," 303; Montefusco, 83-85; Vazzana, 297; Michelangelo Picone, "Dante and the Classics," in Dante; The Critical Complex, vol. II, ed. Richard Lansing (New York: Routledge, 2003), 321-44. 


\section{Uncopyedited draft}

Dante's other works, these references have been more noted than studied. ${ }^{7}$ This essay deals with

Dante's appropriation of Lucan's poem in the Monarchia and in Epistles 5-7: in these texts,

Dante re-deploys materials from the Bellum civile in order to support his philo-imperial agenda.

In anchoring his Christian imperial ideal in the historical precedent of ancient Rome, Dante

applies Lucan's text to the task of exalting the Roman political past, considered as a continuous

historical phenomenon throughout its monarchic, Republican, and Imperial phases. In so doing,

Dante both emphasizes philo-Roman elements already implicit in Lucan's poem and quotes

Lucanian passages out of context, thus adjusting and bending their meaning to serve his own

rhetorical purposes. Dante glosses over Lucan's denunciation of intra-Roman civil wars and

strife, and focuses instead on the conflicts that ancient Rome (viewed as a compact and unified

entity) fought and won against its external enemies. Moreover, Dante re-reads ancient Roman

history as governed by Divine Providence and transforms Lucan's dark, pessimistic account into

a Christian teleological narrative. In the Epistles, Dante claims that true freedom is only possible

under one ruler, and implicitly equates the turmoil of the Roman civil war with the chaos and

anarchy of anti-imperial Florence.

\footnotetext{
${ }^{7}$ See D'Angelo, 467. Dante's quotations of Lucan in his "minor" works are listed in Paratore, "Lucano." Studies on Dante's Cato usually consider the references to this character in the Convivio and Monarchia. Other citations of Lucan in the Rime, Convivio, Monarchia, and Epistles have been analyzed only very sporadically. Dante's reuse of Lucan in the petrose has been noticed in commentaries and specific studies on the Rime: see Robert M. Durling and Ronald L. Martinez, Time and the Crystal: Studies in Dante's "Rime Petrose" (Berkeley: University of California Press, 1990), 421, 375 with bibl. Martellotti mentions Dante's citation of Lucan in Conv. 4.27.2; Guido Martellotti, "Dante e i classici," Cultura e Scuola 13-14 (1965): 125-37; 134-35. Asso tangentially discusses Mon. 2.4.4-6; Paolo Asso, "And Then it Rained Shields: Revising Nature and Roman Myth," in Brill's Companion to Lucan (Leiden and Boston: Brill, 2011), 383-98. Barolini and Buck point out the importance of Lucan in the Monarchia; Barolini, 197; August Buck, "Die Funktion der antiken Auktoren in Dantes politischen Epistole und in seiner Monarchia," in Tradition und Wertung. Festschrift für Franz Brunhölzl zum 65. Geburtstag, ed. Günter Bernt et al. (Sigmaringen: Thorbecke, 1989), 267-76; 275-76. Wilson highlights an allusion to Lucan in Dante's Epist. 6. Andreas Heil, “Dantes 'Thessalien': Pharsalus oder Philippi?” Mittellateinisches Jahrbuch 37 (2002): 75-81, deals with Dante's Epistle 5. The mention of Lucan in the possibly spurious Epistle to Cangrande has received some critical attention: Simone Marchesi, "Lucan at Last: History, Epic, and Dante's Commedia," in Brill's Companion to Lucan, ed. Paolo Asso (Leiden: Brill, 2011), 481-90; 484-85; cf. Fraenkel, 36; Fischli, 33.
} 
In the second book of the Monarchia, Dante claims that the Romans rightfully acquired the empire of the world (imperium mundi). ${ }^{8}$ To corroborate his thesis, he utilizes many quotations of ancient Roman texts, among which is the Bellum civile, investing their words with new meaning in order to underline the legitimate and providential nature of Roman dominion. While fueling the already rich late-medieval debate on imperial and papal power, Dante takes a relatively original approach to the Roman past and to Lucan as a political-historical source. As various scholars have noted, Dante's praise of the Roman political past strongly contrasts with Augustine's view of the pre-eminence of the spiritual over the political, and of the “City of God" over earthly Rome. ${ }^{9}$ In particular, Augustine quotes Lucan to condemn the Romans' violence, heathenism, and thirst for blood. In De civitate Dei [henceforth Civ.] 3.13, for example, Augustine points out how the Romans always fought with each other; in this context, he cites the opening lines of the Bellum civile, in which the civil war between Caesar and Pompey is described in solemnly mournful tones (Lucan. 1.1-2). Likewise, in Civ. 3.27 a quotation of Lucan (2.142-44) is used to point to another famous internal conflict: the struggle

\footnotetext{
${ }^{8}$ The dating of the Monarchia is highly uncertain: scholarly hypotheses range from 1308-10, to $1312-13$, to the years around 1318. The dating 1307-1308 is supported by Nardi, and Pizzica similarly suggests $1308-10$ as the most likely option; Bruno Nardi, ed., Monarchia, in Dante Alighieri, Opere minori, vol. II, ed. Pier Vincenzo Mengaldo et al. (Milan-Naples: Ricciardi, 1979), 264; Maurizio Pizzica, ed., Dante Alighieri, Monarchia (Milan: Biblioteca Universale Rizzoli, 1998), 99-130. Vinay's argument for 1312-13, which I personally find compelling, is also supported by Malato; Quaglioni similarly argues against a later dating; Gustavo Vinay, ed., Dante Alighieri, Monarchia; in appendice: le Epistole politiche (Florence: Sansoni, 1950), XXIX-XXXVIII; Enrico Malato, Dante [Rome: Salerno, 1999], 179-86; Diego Quaglioni, ed., Monarchia, in Dante Alighieri, Opere, vol. II, ed. Marco Santagata [Milan: Mondadori, 2014], 828-37. The dating 1318, or 1316-21, is defended by Cassell and Kay; Anthony K. Cassell, The Monarchia Controversy: An Historical Study with Accompanying Translations of Dante Alighieri's "Monarchia," Guido Vernani's "Refutation of the 'Monarchia' composed by Dante" and Pope John XXII's Bull, "Si fratrum" (Washington, D. C.: The Catholic University of America Press, 2004), 2, 203-4; Richard Kay, trans., Dante's Monarchia (Toronto: Pontifical Institute of Medieval Studies, 1998), XX-XXI.

${ }^{9}$ Gilson points out the difference between Dante's political "monarchy" and the spiritual-religious "city of God" depicted by Augustine; Étienne Gilson, Les Métamorphoses de la Cité de Dieu (Leuven: Publications universitaires de Louvain, 1952), 146-47. On the contrast between Augustine's and Dante's views of ancient Roman virtus as evinced by the Monarchia see also Charles T. Davis, Dante and the Idea of Rome (Oxford: Clarendon, 1957), 47ff.; Carlo Filosa, "La 'virtù' dei Romani nel giudizio di S. Agostino e di Dante," in Dante e Roma, Atti del convegno di studi (Florence: Le Monnier, 1965), 195-210; Cassell, 66-67; Albert R. Ascoli, Dante and the Making of a Modern Author (Cambridge: Cambridge University Press, 2008), 253, with bibl.; Francesca Fontanella, L'impero e la storia di Roma in Dante (Bologna: Il Mulino, 2016), 61-65, 138-39.
} 
between Marius and Sulla. Lucan is among the sources of another passage about the Romans' devotion to war; ${ }^{10}$ moreover, Augustine explicitly mentions Lucan in order to highlight the difference between Christian miracles and pagan marvels, on the grounds that some of the latter were condemned by the pagans themselves. ${ }^{11}$ Again, in Civ. 15.5, Augustine utilizes a line by Lucan about Romulus and Remus (1.95) to prove that Rome's first wall was stained with brotherly blood. ${ }^{12}$ Augustine thus appropriates Lucan's voice as a condemner of Romanitas and a critic of paganism from within. ${ }^{13}$

Dante overturns Augustine's stance and transforms his use of classical texts into an emphatic re-evaluation of the Roman political past that finds very few precedents in the philopapal and philo-imperial treatises of his times. Late-medieval canonists such as Giles of Rome made reference instead to the pre-Roman, biblical-Jewish past in order to attest the Church's superior antiquity and authority. ${ }^{14}$ On the other hand, even a regalist like John of Paris recalled biblical, more than Roman, examples in his De potestate regia et papali. ${ }^{15}$ In contrast, Dante,

\footnotetext{
${ }^{10}$ Civ. 5.12: Bellum civile 7.568 et al.

${ }^{11}$ Civ. 10.16: Bellum civile 6.506.

${ }^{12}$ Cf. Filosa, 205-206; Fontanella, 69.

${ }^{13}$ Augustine's treatise and intertextual strategy will, in turn, be redeployed by a fourteenth-century adversary of Dante's Monarchia. In his De iure monarchiae (post-1386, pre-1402), Guglielmo da Cremona advocates the necessity and legitimacy of papal monarchy as a right transmitted from God to Christ and subsequently to Peter (on the relation between Guglielmo's treatise and Dante's Monarchia, see Guglielmo da Cremona, De iure monarchiae, ed. Cesare Cenci [Verona: Palazzo Giuliari, 1967], 61-63). In his Conclusio 5, the bishop of Cremona attempts to demonstrate the intrinsic superiority of Empire over Republic, which is a point similar to that made by Dante in the second book of his Monarchia, but aimed at authorizing papal, rather than imperial, absolutism. Within this context, Guglielmo inserts Lucan's line about Romulus and Remus, which he draws from Augustine, as an indicator of the evils and fratricides of the Roman Republic (De iure monarchiae, 138, lines 29-30).

${ }^{14}$ Giles of Rome, De ecclesiastica potestate; On Ecclesiastical Power, ed. Robert W. Dyson (New York: Columbia University Press, 2004), part 1.5-6. In his De regimine christiano, Giacomo da Viterbo makes ample use of scriptural and patristic quotations, and draws on Augustine's distinction between the "two kingdoms." The twelfthcentury canonist Richard de Lacy refers to Lucan's witness about the pre-eminence of the Roman Empire as part of the argument he strives to refute; Sergio Mochi Onory, Fonti canonistiche dell'idea moderna dello stato (Milan: Vita e Pensiero, 1951), 253.

${ }^{15}$ John of Paris, Beyond Royal and Papal Power [De potestate regia et papali], ed. Chris Jones (Turnhout: Brepols, 2015), esp. ch. 4-5.
} 
according to whom the Empire was founded on Roman law (Mon. 3.10.8) and existed before the

Church (Mon. 3.12), does not even mention pre-Roman Jews in the Monarchia. ${ }^{16}$

A precedent of some weight for Dante's project can be identified in the writings of

Huguccio of Pisa (d. 1210), a supporter of the supremacy of the Pope, but also of the relative independence of the emperor and of his power over national kings. ${ }^{17}$ In his glosses on Gratian, Huguccio argues in favor of the sovreignty of the emperor ("unus imperator"), citing Lucan's famous phrase "potestas impatiens consortis" and the already mentioned struggle between Romulus and Remus. ${ }^{18}$ The bloody internecine struggles of the Romans, condemned by Augustine, are cited by Huguccio to demonstrate the importance of having a single leader.

Dante's argumentative strategy finds another remarkable antecedent in the De regimine principum of Ptolemy of Lucca (ca. 1236-1327). Although Ptolemy was a papalist launching a fierce attack on imperial monarchy, his treatise, which was likely known to Dante, is characterized by an overall positive view of Roman history, at least in its Republican phase. Ptolemy’s strong admiration for the Roman Republic is, nevertheless, accompanied by a concomitant censure of Caesar's illegal usurpation of power, for which the dictator is said to have been rightly killed. ${ }^{19}$

\footnotetext{
${ }^{16}$ Cf. Cassell, 25, 69.

${ }^{17}$ Huguccio's political doctrine (usually referred to as "dualitas" or "dualism”) is crucial for Dante's Monarchia. Huguccio precedes Dante in claiming that the powers of both the emperor and the pope originate directly and separately from God, that the ecclesiastical and the secular governments should cooperate while preserving their mutual independence, and that the Empire is historically precedent to the Papacy: see Cassell, 13-16. On the importance of Huguccio for Dante (who probably thought of him as both encyclopedist and political polemicist) see also Albert R. Ascoli, "Poetry and Theology," in Reviewing Dante's Theology, vol. 2, ed. Claire E. Honess and Matthew Treherne (Bern: Peter Lang, 2013), 3-42; Id., Dante and the Making (esp. ch. 2).

${ }^{18}$ Mochi Onory, 164-65; Bellum civile 1.92-3 (in Rerum familiarium libri 20.2.5 Petrarch also cites this sentence in connection with the issue of the relative powers of the pope and the emperor).

${ }^{19}$ See Cassell, 73-77; James M. Blythe, ed., Ptolemy of Lucca, On the Government of Rulers: De regimine principum (Philadelphia: University of Pennsylvania Press, 1997), 33-36; cf. De regimine principum 2.9.6; 3.8.5; 3.12.5; 4.1.4. De regimine principum 4.28 .5 contains one quotation from Lucan about the Roman army, which is taken from Isidore however.
} 


\section{Uncopyedited draft}

Compared to these writers, Dante engages in a much more holistic and systematic rewriting of the ancient Roman past by re-adapting a large number of ancient Latin sources. In the second book of the Monarchia, as already in the fourth book of the Convivio, Dante retraces the episodes and deeds through which Rome became a triumphant world power, pointing out that, on all occasions, the Romans acted rightfully, in view of the common good, and with the support of divine providence. Dante always speaks of "Roman authority," without distinguishing between different phases of Roman history, but rather mingling Republican exempla and Imperial claims. He sees only continuity, not contrast, between the courage of Republican heroes such as Cincinnatus, Mutius Scaevola, the Decii, or Cato Uticensis, and the virtue of later emperors. ${ }^{20}$

In this rhetorical context, Lucan's text is re-adapted to highlight the "providential” nature of Rome's history, from its monarchic roots to its Republican and Imperial developments. In so doing, Dante amplifies the philo-Roman stance of some passages of the Bellum civile and often transforms Lucan's pessimistic and polemical account into a glorification of Rome's imperium, which he regards as the basis and root of later imperial constitutions. Unlike Augustine, Dante represents Rome as a compact and solid entity, and elides internal conflicts and civil wars.

In Monarchia 2.4, Dante lists the miracles which allegedly revealed God's favor towards Roman power. Among the marvels that he recalls is the prodigious fall of an ancestral shield from the sky while King Numa was officiating at a sacrifice in Rome, an event that Dante describes by referring to Livy and Lucan: ${ }^{21}$

\footnotetext{
${ }^{20}$ Mon. 2.5-6; Conv. 4.4.10-4.5.20.

${ }^{21}$ This passage raises a philological problem. In fact, the story is not present in Livy: Ab urbe condita 1.20 only makes a generic mention of ancilia and Ab urbe condita 5.54 alludes to "ancilia caelo demissa"; Dante could have known the episode based on other sources such as Ovid, Fasti 3.259-398 and Virgil, Aen. 8.663-65. See Pizzica, ed., Monarchia, 295-96; Quaglioni, ed., Monarchia, 1096: "ma qui, come nota benissimo Vinay, appunto perché alla ricerca di testimoni omni suspicione maiores, come quelli che si richiedono nelle grandi cause e in particolare nella prova del miracolo, 'gli importa citare prima di Lucano uno storico e non, per es., Virgilio"' (the reference is to Vinay, ed., Monarchia, 127: "Ma D. conosce l'episodietto dai suoi corsi di grammatica, come noi, e lo mette sotto le grandi ali di Livio d'istinto perché ricorda vagamente che Livio ne dice qualcosa e gli importa citare prima di
} 
Qua re suum contradictorium concedere sanctum est: romanum Imperium ad sui perfectionem miraculorum suffragio est adiutum; ergo a Deo volitum; et per consequens de iure fuit et est. Quod autem pro romano Imperio perficiendo miracula Deus portenderit, illustrium autorum testimoniis comprobatur. Nam sub Numa Pompilio, secundo Romanorum rege, ritu Gentilium sacrificante, ancile de celo in urbem Deo electam delapsum fuisse Livius in prima parte testatur. Cuius miraculi Lucanus in nono Farsalie meminit incredibilem vim haustri, quam Lybia patitur, ibi describens; ait enim:

Sic illa profecto sacrifico cecidere Nume, que lecta iuventus patritia cervice movet; spoliaverat hauster, aut boreas populos ancilia nostra ferentes. [Mon. 2.4, 4-6; Bellum civile 9.477-80] ${ }^{22}$

Dante offers a selective re-reading of Lucan's lines about Numa: he emphasizes the concept of "marvel” ("cuius miraculi"; "incredibilem vim") and omits Lucan's explanation of this legendary event. Indeed, while describing the effects of the desert wind on Cato's soldiers in Book 9 of his poem, Lucan gives a very skeptical and rationalizing reading of the mythical tale about Numa, suggesting that the reason for the shield's fall could have been simply the power of the wind. ${ }^{23}$ Therefore, Lucan challenges the very idea that the event represents a miracle. Expanding on Lucan's remark, the Commenta Bernensia even claims that Numa craftily arranged the prodigious event himself, by means of some mechanical trick, in order to gain the trust of the Roman people:

\footnotetext{
Lucano uno storico e non, per es., Virgilio, Aen., VIII, 664”). It could also be that Dante here is quoting from memory or from an intermediate source, as I will discuss later (n 32 below).

${ }^{22}$ Dante Alighieri, Monarchia, ed. Pier Giorgio Ricci (Milan: Mondadori, 1965). "Thus the religious thing to do is to concede the contradictory: the Roman Empire was assisted by the support of miracles in attaining its perfection. Therefore it was willed by God, and consequently it existed and exists by right. The testimony of distinguished authors confirms the thesis that God performed miracles as portents in order to bring the Roman Empire to perfection. For Livy, in the first part of his history, attests that when Numa Pompilius, the second king of the Romans, was performing a ritual sacrifice as Gentiles do, a shield fell down from heaven into God's chosen city. In the ninth book of the Pharsalia, Lucan alludes to this miracle in his description of the incredible force of the south wind that afflicts Libya: 'In this way the shields, which chosen patricians carry out on their shoulders, surely fell before Numa as he performed sacrifice: the south wind or the north had robbed the bearers of those shields which now are ours"' (trans. Kay, 117-19; this and all subsequent English translations from the Monarchia are from Kay's translation, indicated by page numbers).

${ }^{23}$ On Lucan's rationalization of the myth, see Asso, 383-84 for a reference to Dante's possible misreading of the passage.
} 
Numa Pompilius ad fidem faciendam Romanis finxit se cum diis habere conloquium et sibi Iovem tertio die pollicitum esse demissurum arma in quendam locum. quae ex praeparato quadam arte mechanica advocato populo visa sunt de caelo venire. ${ }^{24}$

By contrast, in Dante's re-writing the fall of the shield is presented as an unmistakable sign of God's will and favor. ${ }^{25}$ Some critics have supposed that Dante misread Lucan's text. ${ }^{26}$ In my opinion, it is more likely that Dante adopts Lucan's lines rhetorically with attention to only one part in them. Dante appropriates Lucan's words regardless of their original context, and contorts the Bellum civile to fit his own Christian-imperial agenda, but does so in such a way that the fundamental divergence of Lucan's voice is still perceptible for the informed reader. ${ }^{27}$ While Dante's citational method appears in line with the common medieval practice of quoting exemplary passages out of context, ${ }^{28}$ his approach could also be seen as a further confirmation of his creativity and freedom in re-elaborating the Bellum civile, as already underscored by scholars of the Commedia. ${ }^{29}$ However, Dante's hermeneutic attitude to Lucan in his political treatise appears markedly different from the allusive strategies deployed in the

\footnotetext{
24 “In order to gain the Romans' trust, Numa Pompilius pretended he held conversations with the gods and that Jupiter had promised him that, after three days, he would have made weapons fall in some place. Having prepared everything through some mechanical device, Numa summoned the people and it seemed that weapons fell from the sky"; Lucani M. Annaei Commenta Bernensia, ed. Hermann Usener (Leipzig: Teubner, 1869), 302; translation mine).

${ }^{25}$ On Dante's normative, "constitutional" conception of miracles in the Monarchia, see Justin Steinberg, "Dante's constitutional miracles (Monarchia 2.4 and Inferno 8-9)," Lettere Italiane 68/3 (2016): 431-44.

${ }^{26}$ See Angelo C. Volpe, ed., Monarchia (Modena: Società Tipografica Modenese, 1946), 97: "Ma il passo è certamente contro D.; che, o per frettolosità o per inavvertenza, non ha visto che in questi versi c'è una spiegazione illuministica del preteso miracolo dell'ancile caduto dal cielo...”; Asso, 384. Guido Vernani will harshly criticize Dante's stance in his Reprobatio of Dante's Monarchia, but based on other arguments (cf. Cassell, 70-71); Vernani's comment is characterized by the same lack of distinction between Roman Republic and Empire.

${ }^{27}$ Many other examples of Dante's possibly deliberate distortion of classical texts are provided and discussed in Massimiliano Chiamenti, Dante Alighieri traduttore (Florence: Le Lettere, 1995), 119-94 (see 129-34 on Dante's "famous" mistranslations, or rather free translations, of Virgil's Aen. 3.56-57 in Purg. 21.40-41, and of Aen. 1.66465 in Conv. 2.5.14).

${ }^{28}$ For examples in this regard, see Sanford, "Quotations from Lucan in Medieval Authors," American Journal of Philology 55 (1934): 1-19; Margaret Jennings, "Lucan's Medieval Popularity: The Exemplum Tradition," Rivista di Cultura Classica e Medievale 16 (1974): 215-33.

${ }^{29}$ See for example Paratore, "Lucano e Dante," 8; Marsili, 25, 46; Medeossi, 223ff.; Vazzana, 299-300; Montefusco, 98-99, 108.
} 


\section{Uncopyedited draft}

Commedia. In appropriating the Bellum civile within the argumentative context of the

Monarchia, Dante names Lucan explicitly; his choice to emphasize some elements in the poem to the detriment of others goes hand in hand with the deployment of Lucan's text as transparently authoritative.

The continuation of Dante's treatise presents other examples of re-adaptation of Lucan's poem by means of a forced extrapolation, or super-imposition, of a providential, philo-Roman, and monarchist viewpoint. In Monarchia 2.7, Dante explains that God's intention may also be revealed through a proof. One of the possible proofs is a contest between rivals (certamen), a particular instance of which is the direct face-off of two opposing forces (duellum). The fight between Hercules and Antaeus, as recounted by Lucan and Ovid, is recalled by Dante as paradigmatic of this type of contest (Mon. $2.7,9-10) .{ }^{30}$ Dante subsequently moves to consider another kind of certamen, consisting of a competition among various candidates for the same prize, and also explains this case with examples drawn from Lucan. Dante's treatise lists the great past leaders who historically attempted to attain world supremacy. Among them was Xerxes, whose incredible deeds are evoked by a citation of Lucan:

Post hos vero Xerxes, Darii filius et rex in Persis, cum tanta gentium multitudine mundum invasit, cum tanta potentia, ut transitum maris Asyam ab Europa dirimentis inter Sexton et Abidon ponte superaverit. Cuius operis admirabilis Lucanus in secundo Farsalie memor fuit; canit enim ibi sic:

Talis fama canit tumidum super equora Xerxem construxisse vias.

Et tandem, miserabiliter ab incepto repulsus, ad bravium pervenire non potuit. [Mon. 2.8, 7; Bellum civile 2.672-73] $]^{31}$

\footnotetext{
${ }^{30}$ In Mon. 2.9.11, the example of Hercules and Antaeus appears again as representative of the concept of duellum. Dante's choice of this story could have been motivated by the multiple political reverberations with which the encounter between Hercules and Antaeus is charged in the Bellum civile and in the commentary tradition on it. Indeed, Lucan presents this mythical tale as a historical precedent for the later fights between Scipio and Hannibal (Bellum civile 5.656-60) and between the Caesarian Curio and the Pompeian Varus (Bellum civile 5.661ff.); cf. Commenta Bernensia, ed. Usener, 657; Arnulfi Aurelianensis Glosule super Lucanum, ed. Berthe M. Marti (Rome: American Academy in Rome, 1958), 244. Lucan's association of the Hercules-Antaeus with the Scipio-Hannibal conflicts is re-proposed by Dante in Inf. 31.115-18, 131-32).

31 "After these, Xerxes, the son of Darius and king in Persia, invaded the world with so great a multitude of peoples and with such power that he succeeded in crossing the sea that separates Asia from Europe by building a bridge
} 
In the context of the Bellum civile, Xerxes's marine engineering operations in the war against the Greeks are introduced as a precedent for Caesar's siege of Pompey in Brindisi. The difference between the enterprises of the Persian king and of the Roman dictator is, in part, already implicit in Lucan's text, as Xerxes finally lost the war against the Greeks, whereas Caesar was successful in chasing Pompey and ultimately defeating him. Dante makes the contrast between Persian hybris and Roman victory fully apparent and functional to his teleological reconstruction of ancient history.

Another candidate for world dominion was Alexander the Great, who died before he could achieve universal monarchy; Dante's evocation of the Macedonian's death and tomb is based on Livy and Lucan: $:^{32}$

Preter istos et post, Alexander rex Macedo maxime omnium ad palmam Monarchie propinquans, dum per legatos ad deditionem Romanos premoneret, apud Egiptum ante Romanorum responsionem, ut Livius narrat, in medio quasi cursu collapsus est. De cuius etiam sepultura ibidem existente Lucanus in octavo, invehens in Ptolomeum regem Egipti, testimonium reddit dicens:

Ultima Lagee stirpis perituraque proles degener, inceste sceptris cessure sororis, cum tibi sacrato Macedo servetur in antro [Bellum civile 8.692-94].

between Sestos and Abydos. Lucan had this wonderful work in mind when he sang these verses in the second book of the Pharsalia: 'Such, by the report of fame, were the roads built over the sea by the proud Xerxes.' But in the end his attempt was a miserable failure, so he was not able to attain the prize" (159).

32 These lines pose a philological problem, as Livy does not say that Alexander sent ambassadors to the Romans and was killed while he was waiting for their reply. Scholars have speculated on this passage without finding a convincing solution: Martellotti suggests that Dante may be quoting the pseudo-Livy based on a gloss he found on another text (possibly Lucan or Orosius). Paratore thinks that Dante may be influenced by romance traditions about Alexander; Canfora points to the possible role of Orosius as a source on the topic; Guido Martellotti, "Alessandro Magno," Enciclopedia Dantesca I (Rome: Istituto della Enciclopedia Italiana, 1970), 117-19; Cassell, 313n204; Paratore, Tradizione e struttura, 62; Luciano Canfora, Gli occhi di Cesare (Rome: Salerno, 2015), 33ff. In light of Dante's previous passage on Numa, which also presented a combination of the pseudo-Livy and Lucan, I think the answer might be found in medieval commentaries or anthologies where Lucan is systematically associated with Livy and other historical sources. Alternatively, we could explain this as a mistaken quotation from memory, as Kay suggests (159), and indeed the Monarchia contains many imprecisions of this kind. 
"O altitudo divitiarum scientie et sapientie Dei" [Rom. 11.33], quis hic te non obstupescere poterit? Nam conantem Alexandrum prepedire in cursu coathletam romanum tu, ne sua temeritas prodiret ulterius, de certamine rapuisti. [Mon. II, 8, 8-9 $]^{33}$

In this passage, Dante capitalizes on Lucan's disdainful description of the Egyptians to bolster his own philo-Roman discourse. Dante's representation of Alexander as a defeated hero is also in keeping with Lucan's poem: in the Bellum civile, the mention of Alexander's tomb in 8.692-94 (the passage here cited by Dante) finds an echo in $10.20-46$, where it is stated that the Macedonian conqueror was stopped by death. ${ }^{34}$ Already in Lucan, Caesar visits Alexander's sepulchre (10.1-52) and is implicitly represented as the successor of Alexander (and of the Persian kings before him), due both to the breadth of his travels and conquests, and to his thirst for knowledge. ${ }^{35}$ Some medieval commentaries on Bellum civile 8.692-94 also mention Augustus's visit to the tomb, as witnessed by Cassius Dio and Suetonius, thus strengthening the idea of a continuity between Alexander and Roman imperial power:

\footnotetext{
33 "Besides these contenders and after them was Alexander, the Macedonian king, who came closest of them all to winning the palm of monarchy. Through ambassadors he had given the Romans advance warning to surrender to him, but according to Livy he died in Egypt before receiving the Romans' reply, thus collapsing as it were in the middle of the race. Lucan bears witness concerning Alexander's tomb in Egypt while attacking King Ptolemy of Egypt in the eighth book of the Pharsalia, where he says: 'Last scion of the line of Lagus, doomed and degenerate king, who must yield to the scepter of your incestuous sister, though you preserve the Macedonian in consecrated vault.' 'O the depth of the riches of the knowledge and of the wisdom of God!' Who would not be filled with awe by your judgment in this case? For when Alexander tried to trip up his Roman competitor in the race, you pulled him out of the contest before he went any further in his temerity" (159-61).

${ }^{34}$ This passage by Lucan is the basis of Walter of Châtillon's representation of Alexander and his death in the Alexandreis; Maura Lafferty, Walter of Châtillon's "Alexandreis": Epic and the Problem of Historical Understanding (Turnhout: Brepols, 1998), 147-48; Jean-Yves Tilliette, "L'Alexandréide de Gautier de Châtillon. Enéide médiévale ou Virgile travesti?" in Alexandre le Grand dans les littératures occidentales et proche-orientales. Actes du Colloque de Paris (27-29/11/1999), ed. L. Harf-Lancner et al. (Nanterre: Centre des sciences de la littérature de l'Université Paris X, 1999), 275-88; 278-79; Von Moos, 144. In the opening of his poem, Walter contrasts Alexander's and Rome's fame, stating that, had the Macedonian general lived longer, the Romans would have lost their primacy (Alex. 1.1-11). This concept is fiercely contested in Petrarch's Contra eum qui maledixit Italie 166 (ed. Monica Berté, Florence: Le Lettere, 2005) and De viris illustribus 1.15.50 (ed. Guido Martellotti, Florence: Sansoni, 1964); as is well known, Petrarch, like Dante, is also a strenuous advocate for the superiority of the glory of Romanitas over that of Alexander.

${ }^{35}$ See Lafferty, 32ff., 149-51; Christine Ratkowitsch, "Troja-Jerusalem-Babylon-Rom, Allgemeingültiges und Zeitkritik in der Alexandreis des Walter von Châtillon," Poetica 28, no. 1-2 (1996): 97-131; 102-11; Tilliette, 27887; Von Moos, 139-52 with bibl. (in Bellum civile 10.268-85, Caesar wants to know Nilus, like Alexander before him).
} 
[...] inter hos specus est sedes regia in qua regum Alexandriae corpora sunt et Alexandri Magni Macedonis, quem nunc significat. hunc specus cum intrasset Augusto victo Antonio et Cleopatra visendi causa corpus Alexandri, ut propius accessit ad sarcophagum, miratus tam integram formam mentum tetigit digito, cuius hodieque paret vestigium. ${ }^{36}$

The sense of a translatio imperii from the Macedonians to the Romans, which is hinted at in the Bellum civile and in medieval commentaries on it, is significantly amplified by Dante. ${ }^{37}$ Like

Lucan, Dante focuses on Alexander's death and on the end of his extraordinary conquests.

However, according to the author of the Monarchia, it was God who pulled Alexander out of the race to favor the Romans (2.8.10).

Dante extolls the final triumph of the Romans as rulers of the world through quotations of Virgil and Lucan: ${ }^{38}$

Sed quod Roma palmam tanti bravii sit adepta, multis comprobatur testimoniis. Ait enim Poeta noster in primo:

Certe hinc Romanos olim volventibus annis hinc fore ductores, revocato a sanguine Teucri, qui mare, qui terras omni ditione tenerent. [Aen. 1.234-36]

Et Lucanus in primo:

Dividitur ferro regnum populique potentis que mare, que terras, que totum possidet orbem non cepit Fortuna duos. [Mon. 2.8, 11-12; Bellum civile 1.109-11] $]^{39}$

In this passage, Dante twists the meaning of Lucan's words by changing their referent. While in the Bellum civile the lines reported here lament the civil war between Caesar and Pompey, in the

\footnotetext{
36 "Among these caves is a royal mausoleum where are the bodies of the kings of Alexandria and of the Macedonian Alexander the Great, to whom Lucan alludes here. When Augustus entered this grotto, after he defeated Antony and Cleopatra, with the purpose of seeing Alexander's body, he approached Alexander's sarcophagus and, amazed by the fact that the king's body was still intact, touched his chin with a finger. The print can still be seen today" (Comm. Bern., ed. Usener, 281-82, on Bellum civile 8.694, translation mine).

${ }^{37}$ See Flavio Silvestrini, “Iugum libertatis." Dante e la lettura politica del libero arbitrio (Rome: Aracne, 2012), 131-36; and Francesca Fontanella, "L'impero romano nel 'Convivio' e nella 'Monarchia," Studi Danteschi 79 (2014): 39-142; 102-12 for a discussion on certamen and translatio imperii in the second book of the Monarchia. ${ }^{38}$ I treat Dante's integration of Lucan and Virgil in a separate, forthcoming article.

39 "But it is proved by many witnesses that Rome obtained the palm of so great a prize. For our poet says in the first book of the Aeneid: 'Truly, as the years roll on, hence shall spring the Romans; hence the leaders, from the blood of Teucer that lives again, who shall hold sea and land in all-embracing sway.' And Lucan says in the first book of the Pharsalia: '[Rome's] dominion is cleft by the sword, and the fortune of the mighty race that holds possession of the sea, the lands, ay, the whole orb, was too narrow to contain two men"" (161-63).
} 
Monarchia they are provided as evidence that the Roman people, considered as a strong, unified entity, prevailed over all rivals for world supremacy.

Hence, Dante interweaves and re-functionalizes materials from the Bellum civile to demonstrate the divinely sanctioned superiority of the Romans: he both exploits elements already present in Lucan's poem and significantly manipulates the text to his own ends. In contrast to Augustine, who emphasized the internal fights among Romans to condemn their nefarious violence, Dante does not mention Roman civil wars, and regards the conflicts between the Romans and their external enemies as part of God's divine plan. ${ }^{40}$ In Dante's text, Lucan's ambiguous and amoral fortuna becomes God's all-knowing and all-encompassing Providence. ${ }^{41}$ Lucan's skeptical, pessimistic voice is not entirely suppressed in the Monarchia, but it is ultimately bent to Dante's providential perspective. In exemplifying the notion of duellum, Dante recalls the wars between the Romans and the Samnites, again through citations of Livy and Lucan, and states that, in that circumstance, fortune almost changed her mind:

Deinde cum finitimis, omni iure belli servato, cum Sabinis, cum Samnitibus, licet in multitudine decertantium, sub forma tamen duelli, de imperio decertatum fuisse Livius narrat: in quo quidem modo decertandi cum Samnitibus fere fortunam, ut dicam, incepti penituit. Et hoc Lucanus in secundo ad exemplum reducit sic:

Aut Collina tulit stratas quot porta catervas tunc cum pene caput mundi rerumque potestas mutavit translata locum, romanaque Samnis ultra Caudinas speravit vulnera furcas. [Mon. 2.9.16-17; Livy, Ab urbe condita 1.24-26; Bellum civile 2.135-38] ${ }^{42}$

\footnotetext{
${ }^{40}$ The section about duellum (Mon. 2.9.9-21) especially considers the conflicts between Romans and external enemies.

${ }^{41}$ In Mon. 2.9.8, Dante explicitly compares the ancient pagan concept of fortuna and what he asserts to be the superior, Christian idea of "Divine Providence": "Hic Pirrus 'Heram' vocabat fortunam, quam causam melius et rectius nos 'divinam providentiam' appellamus [Here Pyrrhus calls fortune by the name 'Hera,' but we more properly and precisely call that cause 'divine providence']" (169).

42 "Next Livy tells how Rome contended for supremacy with its neighbors, with the Sabines, and with the Samnites. All the laws of war were observed, and although there was a multitude of contestants, still the form was that of a duel. Indeed, while contending in this way with the Samnites, fortune (so to speak) nearly stopped favoring the Romans. Lucan uses this defeat as an example in his second book: 'What heaps of slain encumbered the Colline Gate on that day when the capital of the world and the government of mankind was nearly transferred to a different seat, and the Samnites hoped to inflict on Rome a heavier blow than the Caudine Forks"' (175).
} 


\section{Uncopyedited draft}

Lucan's text is cited by Dante as evidence of the Samnite wars and the defeat at the Caudine Forks in 321 BC. However, Lucan's lines actually refer to the battle of the Collina Gate, fought in 82 BC by Marius (with his Samnite allies) and Sulla. In bringing this civil strife to mind, Lucan compares it to the famous precedent of the Caudine Forks. Dante, in keeping with his rhetorical strategy, omits any reference to the Marius-Sulla civil war and instead focuses on the threat represented by external enemies of Romanitas.

Moreover, in Dante's text, the mention of the wars against the Samnites is followed by examples of other conflicts faced by the Romans: those with the Greeks (Fabricius against Pyrrhus) and with the Carthaginians (Scipio against Hannibal). ${ }^{43}$ The paragraph thus ends with an instance of Roman victory. Dante's teleological perspective redeems and justifies the failures encountered by the Romans in the light of their final triumphs.

Lucan's historical account is profoundly dark and pervaded by bitter irony. Already in the proem, Lucan sarcastically expresses his gratitude to the civil wars, stating that the damage they caused nevertheless led to the establishment of Nero's empire; many medieval commentators perceived the irony of this passage. ${ }^{44}$ Dante's Monarchia aims at evincing the teleology underlying ancient Roman history without any hint of sarcasm; Dante seeks to demonstrate the providential nature of earthly history through, and somewhat against, Lucan's text, thus justifying and legitimizing Roman power, in its monarchic, Republican, and Imperial phases. ${ }^{45}$

\footnotetext{
${ }^{43}$ Mon. 2.9.18.

${ }^{44}$ See Berthe M. Marti, "Literary Criticism in the Medieval Commentaries on Lucan," Transactions and Proceedings of the American Philological Association 72 (1941): 245-54; 252; Ead., "Lucan's Invocation to Nero in the Light of the Medieval Commentaries," Quadrivium 1 (1956): 1-11; Paolo Esposito, "Nerone in Lucano e nell'esegesi lucanea," in Neros Wirklichkeiten. Zur Rezeption einer umstrittenen Gestalt, ed. Christine Walde (Rahden: VML, 2013), 197-216; Eva M. Sanford, "The Manuscripts of Lucan: Accessus and Marginalia," Speculum 9 (1934): 278-95; 284, 289; cf. Tuomas M. S. Lehtonen, Fortuna, Money, and the Sublunar World: Twelfth-Century Ethical Poetics and the Satirical Poetry of the "Carmina Burana” (Helsinki: Finnish Historical Society, 1995), 6869.

${ }^{45}$ In this regard, Cola's commentary on Dante's Monarchia refers to Lucan to illustrate the splendors of the Augustan age. Commenting on Dante's statement that Christ was born under Augustus (Mon. 3.11.7), Cola recalls
} 
A similar re-deployment of Lucan's text in the light of a Christian-imperial view of history is observable in Epistles 5-7, which Dante wrote in the years 1310-11 in support of Henry VII's Italian expedition. ${ }^{46}$ These letters mingle classical and biblical citations to extol Henry's divine mission. In them, Dante capitalizes on some elements of the Bellum civile, and particularly transforms Lucan's denunciation of the civil war into a justification of political absolutism.

Like the Monarchia, Epistle 5 also highlights the progressive revelation of God's will throughout ancient history, from the Trojans to Augustus, and represents the sovereign as the successor of the great emperors of ancient Rome ("et Augustus et Caesar"). ${ }^{47}$ Like the treatise, therefore, this letter posits that the Holy Roman Empire of Dante's times is a continuation of the ancient Roman kingdom, seen as a unified and continuous historical reality. In Epistle 5, Dante also overturns common anti-imperial notions of political freedom, stating that libertas is only possible within a political system regulated by justice, and thus under the guidance of an

the emperor's deeds and writes: “Qui sic in universo orbe regna mundi in sui voluntate pacata conspexit, ut populus romanus iam Belligeri Martisque templa conclauderent et exigerent templum Pacis omniaque insuper arma convertent in vomeres et cassides in ligones, prout Lucanus in primo Pharsalie de temporibus illis loquens ait: 'Inque vicem gens omnis amet, pax missa per orbem / ferrea belligeri compescat limina Iani [He saw all the kingdoms of the world pacified under his will, in such a way that the Roman people closed the temples of the belligerent Mars and built a temple to Peace, and moreover converted all weapons into ploughshares and all helmets into mattocks, as Lucan says in the first book of the Pharsalia, talking about those times: 'let all nations love one another; let Peace, sent forth to all lands, shackle the iron gates of warlike Janus']"; Cola di Rienzo, In Monarchiam Dantis Commentarium, ed. Paolo d'Alessandro (Vatican City: Scuola di Paleografia, Diplomatica e Archivistica, 2015), 118-20; Bellum civile 1.61-62 (the translation of Cola's text is mine, that of Lucan's lines is taken from Jane W. Joyce, transl., Pharsalia; Lucan [Ithaca: Cornell University Press, 1993], 5).

${ }^{46}$ See Davis, 142ff. on the relation between Epistles 5-7 and the Monarchia, and 163-69 for an analysis of these epistles; cf. Vittorio Russo, Impero e stato di diritto. Studio su "Monarchia” ed "Epistole” politiche di Dante (Naples: Bibliopolis, 1987), 64-66.

${ }^{47}$ Ep. 5.1-2, 8; Dante Alighieri, Epistole, ed. Claudia Villa, in Dante Alighieri, Opere, vol. II, ed. Marco Santagata (Milan: Mondadori, 2014). As has been noticed, in the opening of this letter Dante mentions Augustus's expedition to Thessaly and thus conflates the battles of Pharsalus and Philippi; the passage is primarily based on Florus but potentially draws also from other ancient sources, including Lucan and Virgil (Villa, ed., Epistole, 1543; Heil; Fontanella, L'impero, 175-76). 
enlightened ruler. This concept, which is at the very basis of Dante's political thought, is strongly reasserted in Dante's subsequent letter, addressed to the Florentines who opposed the emperor. ${ }^{48}$

In the opening of Epistle 6, Dante claims again that Providence has ordained that humankind must be governed by the Holy Roman Empire so that it may find peace. ${ }^{49}$ The author dwells on the idea that, while Florentines think they are free, they are in fact slaves, and their "falsa libertas" is very different from the true freedom which derives from respecting the laws. ${ }^{50}$ Florence's opposition to the emperor is equated with an unjustified resistance to the decrees of the "eternal senate," and the Florentines are rebuked through the words "O male concordes," with an echo of Lucan's apostrophe to the leaders of the civil wars ("O male concordes nimiaque cupidine ceci!"). ${ }^{51}$ Dante's text therefore suggests that the traditionally Republican ideal of libertas finds its fulfillment under the leadership of an enlightened emperor, who can avert the danger of civil war.

There follows a gloomy forecast of the future of Florence's nefariously chaotic political and civic life; Dante claims that the plebs' lack of leadership will be more and more apparent in the city: "Videbitis plebem circunquaque furentem nunc in contraria, pro et contra, deinde in idem adversus vos horrenda clamantem, quoniam simul et ieiuna et timida nescit esse" (Ep. 6. 4). ${ }^{52}$ These lines call to mind Lucan's phrase "Nescit plebes ieiuna timere [starving, the rabble

\footnotetext{
${ }^{48}$ See Villa, 1541, on the idea of freedom under a ruler in the episode of Cato in the Purgatorio; Fontanella, "L'impero romano," 88-97; Ead., L'impero, 95-103, on this notion as stated in Monarchia 1.12.8; Silvestrini on this concept in Dante's various political works (on the political epistles, see 53-54, 74-75, 105-6, 164-65, 229-31).

${ }^{49}$ Ep. 6.1 .

${ }^{50}$ Ibid., 6.3-5.

${ }_{51}^{51}$ Ibid., 6.3; Bellum civile 1.87; "Men in evil accord, blind with excessive avarice!," trans. Joyce, 7; cf. Villa, 1548.

52 "The populace which now, divided against itself, rages indiscriminately, some for you, some against you, you shall then see united in their imprecations against you, for the starving mob knows nothing of fear"; trans. Paget J. Toynbee, Dantis Alagherii Epistolae; The Letters of Dante (Oxford: Clarendon, 1966, 2nd ed.), 79.
} 


\section{Uncopyedited draft}

knows no dread]." 53 In the Bellum civile, this statement is a polemical comment on Caesar's cynically demagogic policy of wheat distribution; in Dante's text, they are incorporated into the description of the evils of anarchy and thus authorize autocracy. ${ }^{54}$

The rhetorical strategy of Epistles 5 and 6 finds its completion in Epistle 7. This letter is directly addressed to Henry VII, once more presented by Dante as the king of the Romans, the heir of both Caesar and Augustus, and the leader best able to restore peace and renew the Golden Age once celebrated by Virgil. ${ }^{55}$ Rebuking the emperor for procrastinating in northern Italy, Dante calls attention to Tuscany. He blames the evils of the Tuscan tyranny ("Tuscana tyrannis"), and urges Henry to intervene by quoting Curio's advice to Caesar and Mercury's exhortation to Aeneas:

Pudeat itaque in angustissima mundi area irretiri tam diu quem mundus omnis expectat; et ab Augusti circumspectione non defluat quod Tuscana tyrannis in dilationis fiducia confortatur, et cotidie malignantium cohortando superbiam vires novas accumulat, temeritatem temeritati adiciens. Intonet iterum vox illa Curionis in Cesarem: "Dum trepidant nullo firmate robore partes, tolle moras; semper nocuit differre paratis: par labor atque metus pretio maiore petuntur." Intonet illa vox increpitantis Anubis iterum in Eneam: "Si te nulla movet tantarum gloria rerum, nec super ipse tua moliris laude laborem, Ascanium surgentem et spes heredis Iuli respice, cui regnum Ytalie Romanaque tellus debentur." [Ep. 7.4; Bellum civile 1.280-2; Aen. $4.272-76]^{56}$

\footnotetext{
${ }^{53}$ Bellum civile 3.58; (trans. Joyce, 57); cf. Pastore Stocchi, ed., Dante Alighieri, Epistole; Ecloge; Questio de situ et forma aque et terre (Rome: Antenore, 2012), 48. Wilson identifies another allusion to Bellum civile 7.186-87 in Dante's Ep. 6.4 (praesaga mens).

${ }^{54}$ In keeping with his problematization of the concept of "freedom," Dante states that, because of its servility ("pro servitute") Florence will suffer the calamities that Saguntum experienced because of its commitment to liberty ("pro libertate"; Ep. 6.4). This reference to the ancient city besieged by Hannibal during the Second Punic War is a reassertion of the relationship of filiation between ancient Rome (seen in both its Republican and Imperial phases) and Henry VII's pacifying rule as imagined by Dante. Baglio relates this Dantean passage to Bellum civile 3.349-50, where, in resisting Caesar's siege, the inhabitants of Marseille compare their desire for libertas to that of ancient Saguntum (Dante Alighieri, Epistole; Egloge; Questio de aqua et terra, ed. Marco Baglio et al. [Rome: Salerno, 2016], 146). In Dante's text, however, true freedom is equated with submission rather than resistance to the Roman emperor.

${ }^{55}$ Ep. 7.1; cf. Mon. 1.11.1, which includes a quotation of Virgil, Eclogues 4.6.

56 "Let him, then, for whom the whole world is looking, be ashamed to be entangled so long in such a narrow corner of the world; and let it not escape the consideration of Augustus that the tyrant of Tuscany is encouraged by the assurance that he is delaying, and daily by appealing to the pride of the evil-doers gathers fresh strength, heaping daring upon daring. Let the voice of Curio to Caesar be heard once again: 'While the factions are in confusion and without support, away with delay! delay was ever the bane of the ready - equal toil and fear are more dearly bought.' Once again let the voice of Mercury chiding Aeneas be heard: 'If the glory of such mighty deeds leave thee
} 


\section{Uncopyedited draft}

As many scholars have noticed, Curio's words are here refunctionalized, free from the negative connotation they have in the Bellum civile and in Dante's Inferno 28: in Epistle 7, Dante himself appropriates Curio's words to prompt the emperor to action. ${ }^{57}$

Towards the conclusion of the epistle, Florence is depicted as a viper turning against her mother, Rome ("vipera versa in viscera genetricis") ${ }^{58}$ While referring to a common legend about vipers, transmitted for example by Isidore (Etym. 12.4.10), the text also recalls the opening of the Bellum civile, where the victorious Roman populace is said to turn against its own bowels ("in sua victrici conversum viscera dextra"). ${ }^{59}$ Here, as in the previous epistle, the damage of the Roman civil war, as represented by Lucan, is associated with the harm of anti-imperial opposition and anarchy in fourteenth-century Italy. Political chaos is equated with slavery, whereas Henry VII, seen as the successor of Caesar, is praised as the ruler who can restore justice and thus freedom.

The above analysis has shown how Dante re-fashions Lucan's text in order to underpin his own, Christian-imperial agenda. In my opinion, however, Dante's willingness to "correct" his source-text should not be overemphasized, nor does his re-writing of the Bellum civile necessarily entail a polemical or antagonistic attitude towards Lucan. Contemporary studies have

unmoved, and thou wilt not exert thyself for thine own fame's sake, yet consider the young Ascanius, Iulus thine hope and heir, to whom are due the kingdom of Italy and the land of the Romans""; trans. Toynbee, 102-3). See also Epist. 7.8: "Eia itaque, rumpe moras"; cf. Aen. 4.569.

${ }^{57}$ See for example Paratore, "Lucano e Dante," 8-9; cfr. Id., "Lucano," 698; Baglio, 167 with bibl. Line I, 281 is one of the lines of the Bellum civile most frequently quoted by medieval authors, who often reuse it as an exhortation to political and military leaders; cf. Eva M. Sanford, "Quotations," 5; De Angelis, 147n7).

${ }^{58}$ Ep. 7.7: "She is the viper that turns against the vitals of her own mother"; transl. Toynbee, 104.

${ }^{59}$ Bellum civile 1.3; Baglio, 174 also points to Virg., Aen. 6.833: "neu patriae validas in viscera vertite vires." Another interesting precedent for this passage by Dante can be found in Ambrosius, Epist. 8.57.14. Talking about civil strife, Ambrosius seemingly alludes to Lucan: “...misere in sua populum conversum viscera et bello civili utrimque afflictum" (italics mine). In a previous passage of his letter, Dante exhorts the emperor to imitate the "magnanimous" Hercules and kill the Hydra (Ep. 7.6); as Baglio notices, the adjective magnanimus comes from Bellum civile IV, 611: magnanimum Alciden (Baglio, 170). 
highlighted the ideological complexities of Lucan's poem, which, far from being a single-minded

Republican pamphlet, is characterized by strong internal tensions and contains both an anti-

Caesar and a pro-Caesar discourse. ${ }^{60}$ Scholars have also pointed out that medieval and early-

humanist authors repeatedly drew from the Bellum civile to substantiate their pro-monarchist

claims, grasping somewhat the inner tensions of Lucan's narration and exploiting its philo-

Caesar elements. ${ }^{61}$

I believe that Dante's approach to Lucan should be viewed against this background. As we have seen, in his eulogy of ancient Rome, Dante conflates Roman Republican and Imperial values, and builds on philo-Roman elements that are, to some extent, already present in Lucan's poem. What is more, scholars have often noticed that Dante references Lucan in the Commedia to commend the virtue of the anti-Caesarean Cato and to trace an ambivalent portrait of Caesar's personality, while at the same time praising the latter's energy and efficiency (still based on Lucan) and his providential role as "the first Roman emperor." 62 Therefore, it is likely that Dante

\footnotetext{
${ }^{60}$ On the ideological complications of Lucan's text, see Jacqueline Brisset, Les idées politiques de Lucain (Paris: Les Belles Lettres, 1964), 35-223; Jamie Masters, Poetry and Civil War in Lucan's "Bellum Civile” (Cambridge: Cambridge University Press, 1992), esp. 1-10, 87-9; Shadi Bartsch, Ideology in Cold Blood: A Reading of Lucan's "Civil War" (Cambridge: Harvard University Press, 1997), esp. 1-9, 73-100); W. R. Johnson, Momentary Monsters: Lucan and his Heroes (Ithaca and London: Cornell University Press, 1987).

${ }^{61}$ See Violetta De Angelis, "Il testo di Lucano, Dante e Petrarca," in Seminario Dantesco Internazionale. International Dante seminar 1: Atti del primo convegno tenutosi al Chauncey Conference Center, Princeton 21-23 Ottobre 1994, ed. Zygmunt G. Baranski (Florence: Le Lettere, 1997), 67-109; 76-81; Edoardo D’Angelo, “La Pharsalia nell'epica latina medievale," in Interpretare Lucano: miscellanea di studi, ed. Paolo Esposito and Luciano Nicastri (Naples: Arte Tipografica, 1999), 389-453; 411-15; Jeremy DuQuesnay Adams, "The Influence of Lucan on the Political Attitudes of Suger of Saint-Denis," in Proceedings of the Twelfth Annual Meeting of the Western Society for French History, ed. John F. Sweets (Albuquerque: Western Society for French History, 1985), 1-11; Christopher Bond, "Lucan and the Christian Monarchist: The Anti-Republicanism of the De tyranno and the De bello civili," Renaissance Studies 20 (2006): 478-93. On the diverse historical reception(s) of Lucan's text and its political ambivalences, including pro-monarchist re-uses of the poem, see also Charles Martindale, Redeeming the Text. Latin Poetry and the Hermeneutics of Reception (Cambridge: Cambridge University Press, 1993), 64-74; Id., Latin Poetry and the Judgement of Taste (Oxford: Oxford University Press, 2006), 217-36; Edward Paleit, War, Liberty, and Caesar. Responses to Lucan's “Bellum Civile," ca. 1580-1650 (Oxford: Oxford University Press, 2013), esp. 17-24, 93-127, 202-5.

${ }^{62}$ For an overview see Paratore, "Lucano e Dante," 6-12; Id., Dante e Lucano, 9, 12-23, 33-43; Id., "Lucano," 7012; De Angelis, “... e l'ultimo Lucano"; Weigel; Scott, "Cato"; Id., Understanding Dante, 247-50; Manescalchi; Clogan; Boggione; Mazzotta, 14-65; Stull-Hollander, 33-42; Marchesi; Walde, 72-3; Wetherbee, "Poeta che mi guidi"; Montefusco, 103-4 with bibl. Dante's activity in the years of Henry VII's expedition may have included
} 
appreciated Lucan's criticism of Caesar and the horrors of the civil war, and yet read the Bellum civile as an account of Caesar's military triumphs and of the necessary struggle leading to the establishment of the divinely ordered Roman Empire. ${ }^{63}$

In this regard, we should note that Dante's re-use of Lucan in the context of his exaltation of ancient Rome as expressed in the Monarchia and the political epistles finds an ideal parallel and culmination in Paradiso 6. Here, Dante's historical-political analysis is transposed poetically: through the mouth of Justinian, Dante retraces the history of Rome's irresistible ascension from the times of Ascanius to those of Caesar and beyond, until Charlemagne (Par. 6.1-96). Dante once again conflates Roman monarchic, Republican, and Imperial exempla, in keeping with the rhetorical strategy of Convivio 4 and Monarchia $2 .{ }^{64}$ Combined with Virgil's and Florus's texts, Lucan's Bellum civile once more informs and underpins Dante's teleological re-reading of the Roman past: in this canto, the history of the Roman civil wars and of Caesar's defeat of Pompey is recounted as part of the divinely orchestrated rise of the Roman Empire, viewed as an instrument of redemption. ${ }^{65}$

\footnotetext{
some drafting (or revising) of the Monarchia alongside the epistles, which might also account for the differences in Dante's reuse of Lucan's descriptions of Caesar between the Inferno (ca. 1304-8) and the later cantiche (ca. 1308/10-13 and 1316-21). Indeed, Inferno 4 reactivates the dark side of Lucan's portrayal of Caesar: "Cesare armato con li occhi grifagni" (Inf. 4.123): see Paratore, "Lucano e Dante," 8; Montefusco, 103-6; Scott, "Cato," 81; Fischli, 37. By contrast, in Purgatorio 18 and Paradiso 6, the pro-Caesar subtext of Lucan's poem is evoked to praise Caesar's incredible rapidity and efficiency (see Paratore, "Lucano e Dante," 11-12; Id., "Lucano," 700; Marsili, 3536; Pastore Stocchi, "Cesare," 223-24; La Penna; Fontanella, L'impero, 260-1). Dante's systematic re-reading of ancient Roman history from a Christian monarchist perspective in the years 1310-13 might have contributed to determine his differently selective approach to Lucan's contrasting representations of Caesar throughout the Commedia.

${ }^{63}$ As I claim in an article forthcoming in Humanistica, Petrarch is also likely to look at Lucan's text as politically nuanced, rather than resolutely anti-Caesar, and also activates the ambiguities of the Bellum civile to produce an ambivalent representation of Caesar while constantly advocating the necessity of a strong leader.

${ }^{64}$ See Fontanella, L'impero, 302-6; cf. 6-7 above. On Dante's mingling of Roman Republican and Imperial elements in the Commedia see Robert Hollander and Albert L. Rossi, "Dante's Republican Treasury," Dante Studies 104 (1986): 59-82.

${ }^{65}$ See Fontanella, L'impero, 310-15 with bibl.
} 